\title{
PUBLIC ADMINISTRATION REFORM \\ IN CROATIA: SLOW MODERNIZATION \\ DURING EUROPEANIZATION \\ OF RESILIENT BUREAUCRACY
}

\author{
Ivan Koprić \\ Professor, Head of the Chair of Administrative Science \\ at the Faculty of Law, University of Zagreb, \\ President of the Institute of Public Administration, Croatia. \\ Address: University of Zagreb, Trg Republike Hrvatske 14, \\ 10000 Zagreb, Croatia. \\ E-mail: ivan.kopric@pravo.hr
}

\begin{abstract}
Over-politicization co-exists in the Croatian public administration with legalism, formalism and red tape. Low reform, innovation and initiative capacities are among the results of such an administrative model. Croatia has a relatively big and strong but inefficient public administration. Internal bureaucratic resistance to modernization is observable. Foreign actors play a moderate role in administrative reform. The European Union has exerted the strongest influence on modernization on the basis of conditionality policy, insistence on the administrative capacity building, and the European Semester procedure. E-government policy, transparency, and strategic planning are the reform areas with the above-average reform results.
\end{abstract}

Keywords: public administration reform - Croatia; modernization; Europeanization; resilient bureaucracy; reform outcomes; European Semester.

Citation: Koprić, I. (2019). Public Administration Reform in Croatia: Slow Modernization During Europeanization of Resilient Bureaucracy. Public Administration Issue, Special Issue I (electronic edition), pp. 7-26 (in English); DOI: 10.17323/1999-5431-2019-0-5-7-26.

\section{Introduction}

The Croatian public administration reform has been conducted in a patchy manner, although continuously under the notion of Europeanisation. The process of Europeanisation started in a top-down manner only a few years after the war, which in some parts of Croatia officially ended in January 1998. Dominant 
politics has had a decisive role. In the newest stage citizens, civil society and academia have gained some influence on the reform processes. Hard neoliberal reform measures have not been accepted by domestic political actors, at least not in their radical forms, although the Croatian business community has strongly advocated for structural reforms in line with the New Public Management doctrine. Croatia has a relatively big and strong but inefficient public administration. About 293,000 employees or about 17 per cent of the workforce is employed by the state, according to the World Bank. The share of public wages in GDP in 2014 was 11.8 per cent (WB, 2016: p. 43-44). However, more detailed data show there are about 317,000 employees or more than 18 per cent of the workforce employed by the state (Koprić, 2017). The Croatian government effectiveness percentile ranking at the Worldwide Governance Indicators in 2015 was 72, in comparison to 88 for the OECD countries (WGI, 2015). The size of the public sector, administrative tradition and the existence of a number of influential trade unions have prevented or delayed administrative reforms. Internal bureaucratic resistance to changes is also observable. Foreign actors play a moderate role, except the European Union, whose conditionality policy and insistence on the administrative capacity building have exerted a significant influence on administrative modernization.

At the end of the 1990s, two issues were initially addressed by the then Government, decentralisation and the integration into the European Union. The new task of democratization was added after the first significant political change in 2000 . Namely, the 1990s were the years of strong etatisation and centralization. Certain important parts of state administration were developed from scratch, such as diplomacy, customs service, army, intelligence service, certain components of internal affairs and the police service, etc. The strong position of local self-government, developed during socialism, was significantly diminished in the reform of 1993. The governance system was characterized by a strong central executive responsible to both the Croatian Parliament (Hrvatski sabor) and to President of the Republic. The position of President Tuđman was particularly powerful, since he had direct hierarchical competencies over the Government and the county governors. The strong political position of his political party (HDZ) significantly strengthened his influence. He led the country from 1990 to his death at the end of 1999. Bureaucratization and a climate of secrecy were among the main characteristics of the then governance system.

Privatization at the beginning of 1990s was connected with the general transformation of the former "social ownership" of companies into either private or state ownership, in parallel with the introduction of market economy. In the public sector, privatization was delimited to certain services and sectors, such as primary healthcare, telecommunications, or road transport. It took place mostly during the 1990s and was connected with general privatisation trends in many other European countries, under the influence of new public management ideology. Still, many services were retained in the public sector, and a significant part of them was transferred from local to the central state control. The role of local governments in the provision of public and social services was significantly weakened in comparison to the socialist period. 
An additional path of centralization was connected with the position of newly established counties and their governors. Counties were units responsible for deconcentrated state administration with, in addition, a rather limited autonomous scope. Furthermore, although county governors were elected by the county assemblies, they were state functionaries who had to be confirmed by the central state authorities. The President of the Republic was authorized to give or refuse such confirmation on the Government's proposal, without any reasons. Such position of county governors was under particular scrutiny of the Council of Europe after the Croatian ratification of the European Charter of Local Self-Government in the autumn of 1997. Croatia did not accept certain important Charter's provisions, such as those provided for in Article 4 paras. 3, 5 and 6, Article 8 para. 3, Article 9 paras. 5 and 7 and Article 10 para. 2. The remaining Charter provisions were ratified only in 2008. However, even the ratification of the minimum number of Charter provisions in 1997 triggered the issues of county governance democratization and overall decentralization of the country at the end of the 1990s.

\section{Main Topics of and Content of the Reform Agenda}

\section{Transparency and Accountability Mechanisms}

Efforts to build an open and transparent public administration has been one of the main reform processes in Croatia, which is to a large degree facilitated by the harmonization with EU standards and fuelled by the conceptual considerations about good European governance. Transparency means making public data and information accessible to the public by efforts of public bodies, while openness means enabling citizen' feedback, comments, proposals, and criticism (comp. Musa, 2011). Accountability mechanisms are focused on financial aspects of the functioning of public administration, including internal financial control and external audit. Sound regulation of public procurements, concessions and public-private partnerships with modernized and ICT-supported public procurement procedures may be added. Improved regulation and better implementation of public procurements, concessions, and public-private partnerships might narrow the space for corruption, but an effective anti-corruption policy also needs other mechanisms connected with transparency, openness and accountability of public administration.

The first Croatian Right to Access Information Act was adopted at the end of 2003 and amended in 2010. The right to access public sector information was proclaimed a constitutional right by the Constitutional Amendments of 2010. The number of cases initiated at citizens' request has been more or less constant, after the first high wave. The highest number of requests was in $2004-19,600$. There were 4,499 requests in 2005, 4,357 in 2006, 3,670 in 2007,2,730 in 2008, and 3,173 in $2009,12,340$ in $2010,51,930$ in $2011,53,521$ in $2012,24,330$ in $2013,21,078$ in 2014, 18,007 in 2015, and 17,059 in 2016.

A new step in developing transparent public administration was made by the appointment of the first Croatian Public Information Commissioner in 2013. The Commissioner has the task to provide legal protection of the right to access public 
sector information and reuse such information (open data), and to monitor and promote these rights. In one of her reports (23 ${ }^{\text {rd }}$ September 2014), Public Information Commissioner, Anamarija Musa, stressed that the largest number of appeals were submitted because of the silence of administration (practice of not responding to citizens' requests for public information), and that only 15 per cent of appeals were refused, which means that 85 per cent of appeals had firm legal grounds. The number of requests for usage of open data is rather low, witnessing that the usage of such data for economic and other purposes in Croatia is at the very beginning.

According to the 2015 Report, in the newly established Registry of Public Bodies there were data about 6,045 bodies and about 4,425 information officers in such bodies. At the beginning of 2016, an Internet application was established for all public bodies to report about their realisation of the right to public information. By mid-February 2016 as many as 4,539 public bodies submitted their reports. However, there were 23.6 per cent of public bodies that resisted reporting, and about 20 per cent of bodies have never appointed their information officers. In 2015, the aforementioned 4,539 bodies received 18,007 requests for public information and 898 requests for reuse of public information. Public bodies replied positively to almost 85 per cent of requests, mostly within legal deadlines (Izvješće, 2016). Improvements indicate better effectiveness of the institutional framework for public sector transparency, upgraded preconditions for access to public sector information (better design of internet pages, easier internet access, better-structured information, etc.), and stronger trust in the public sector. Additional improvements are noticed in the 2016 Report: more than 93 per cent of the requests were positively resolved in 2017 . The majority of other indicators were better than in the previous year (Izvješće, 2017).

The Government adopted the Code of Practice on Consultation with the Interested Public in the Process of Adopting Laws, Other Regulations and Policies in November 2009. The 2011 Regulatory Impact Assessments Law introduced obligatory public consultations about new regulations. The central internet portal for public consultation has been functioning since the spring of 2015. Only 48 laws and regulations $(1 / 3)$ underwent public consultations in the first year of application (2011) and 173 comments were received. In 2012, the number of regulations which were opened to public consultation increased to 144 (4,786 comments received). The number increased further to 374 in 2013 (12,738 comments), 544 in 2014 (18,767 comments), 608 in 2015 (15,411 comments), and 642 in 2016 (12,856 comments). The new Regulatory Impact Assessment Law has been in force since May 2017.

The State Audit Office was established in 1993. Based on both external and internal assessments, it gained constitutional status through the constitutional amendments of 2010. Its new position was regulated by the Law on the State Audit Office of 2011, ensuring its legal, organizational, financial and functional independence. The system of internal financial controls was introduced based on the Law of 2006. The Law on the System of Internal Financial Controls in the Public Sector of 2015 was intended to modernize it and widen its scope to public companies and other legal persons in state or local ownership. 
The first regulation of public procurements in light of EU standards was made by the Law on Public Procurements of 2001. This was accompanied by the Law on State Commission for the Supervision of Public Procurement Procedures of 2003. These laws enabled the establishment of a second-instance quasiindependent body for deciding about appeals in public procurement procedures. The scope of the mentioned State Commission was widened to the control of firstinstance decisions about concessions and public-private partnerships by the Law of 2010. The third Law on State Commission of 2013 (amended in 2014) was focused on harmonization with EU law and further strengthening of the Commission's organizational capacity and autonomy.

The Law on Public Procurements of 2007 was intended to harmonize the Croatian legislation with changes in EU law and to introduce modernization of public procurement procedures. It enabled the establishment of the first official electronic platform for electronic public procurement during 2008. The Law on Public Procurements of 2011 was intended to harmonize legal regulation of public procurements in Croatia with the newest changes in EU law. Further development of electronic public procurement is one of the main intentions of the Law on Public Procurement adopted at the end of 2016. It has been in force since $1^{\text {st }}$ January 2017.

The bombastically announced policy of public-private partnership has achieved rather poor results. After the adoption of the Guidelines for Application of Contractual Forms of Public-Private Partnerships by both the Government and the Parliament in 2006, the first Law on Public-Private Partnerships was adopted in 2008. It was the base for only three PPP projects by 2012. Because of that, the new Law on PPP of 2012 contains more detailed and precise regulation which facilitates the usage of PPPs. However, the number of such partnerships has remained rather small (18 approved and registered projects until 2015). The Law was amended in 2014.

Despite the huge complexity of regulation in the area of concessions, they are a frequently used form of performing public tasks. There were as many as 119 types of concessions and about 6,800 concession contracts before the adoption of the Law on Concessions of 2008 (Medvedović, 2013). Its main purposes were harmonization with EU law and introduction of generally applicable regulation to all sorts of concessions. The new Law on Concessions of 2012 was justified by harmonization with the newest changes in EU law. Similar justification was used for the new Law on Concessions of 2017. It has been in force since July 2017.

It may be noted that Croatia has actively participated in the Open Government Partnership initiative since 2011. In 2012 OGP Council was established. Its main tasks are preparation of action plans and coordination of activities focused on implementation of transparency and openness policy.

The perception is that corruption in Croatia is rather widespread, although anti-corruption efforts have produced moderately positive results. Croatia achieved the best score in 2015, when it was in $50^{\text {th }}$ place with a score of 51 on the Transparency International's 2015 Corruption Perceptions Index list, improving on its $67^{\text {th }}$ place in 2004, when it was confirmed as an EU candidate country. However, in 2016 the score dropped to 49. Structural problems (numerous local govern- 
ments, overlapping competences, very complicated structure of deconcentrated state administration, etc.) open space for unethical behaviour in public administration. It seems that ethical problems are even worse at the local level. Two strategic anti-corruption documents (2008 and 2005) offered an array of measures for combating corruption of all types and at all governance levels. Several criminal charges of top politicians at the central, regional, and local levels are signs of the fight against corruption. However, a majority of anti-corruption measures is still of normative and institutional nature. Proper general administrative education and quality in-service training are important measures in combating corruption because they strongly influence the adoption of high ethical standards. However, they are only moderately developed in Croatia. Training in combating corruption, public campaigns warning about its disruptive effects, and similar measures may be additional anti-corruption tools but cannot replace firm ethical standards of well-educated professionals. An indicator of weak political support to anti-corruption measures was the resignation of the president of the Ethical Commission for the Civil Service (see below) in 2015 after her continuous complaints about lack of communication with the Government and with the Ministry of Public Administration, and her warnings about other problems in the treatment and functioning of the Commission.

\section{Civil Service System and Human Resource Management}

The civil service system is regulated by three main laws: the State Servants Law (2005; previously the Law on State Servants and Employees of 1994 and 2001), the Law on Servants and Employees in Local and Regional Self-Government (2008), and the Law on Salaries in Public Services (2001; it only regulates the pay system in public services financed by the State Budget). In the whole public sector, there are four categories of civil servants and other professionals whose status is regulated separately by special legislation. There are approximately 59,500 civil servants and employees in the state administration, not counting military and intelligence service personnel and police officers. In all local governments and counties, there are approximately 14,500 executive functionaries with professional status, civil servants, and employees. Centrally-financed public services employ more than 180,000 people (including those in agencies, funds and other bodies), and locallyfinanced public services have an additional 26,500. The fifth category in the public sector comprises the employees of public companies whose status is regulated by the Labour Act, e.g., in utility services, state oil company, state postal service, state electric power industry, and the like (about 88,500).

The State Servants Law of 2005 established the base for a more modern civil service practice. The Ministry of Public Administration is the main competent body. Job analysis is one of the most complex tasks performed on the basis of that Act, with numerous problems, misunderstandings and resistances (Ratković, 2008). Work plans are still not common in administrative organizations. Performance measurement has been regulated but still does not function properly. Pay for performance has never started to function, neither at the national nor at local levels because of the tight budgetary framework and lack of political will (Manojlović, 2016). A strategic approach towards development of the civil ser- 
vice was promoted by the Strategy of Human Potentials Development in Public Administration in the Period 2010-2013. The new registry of civil servants was established in 2012, including state, local, and public servants. Annual personnel planning, the new public administration ethics system, and the system of in-service training are the main three novelties which can be positively assessed.

The first Ethical Codex for State Servants was adopted by the Government in 2006 and amended in 2008. The Ethical Commission started to function in May 2009. A new Ethical Code of Civil Service was adopted in 2011 and amended in 2012. Citizens can report any breaching of ethical standards in the civil service to the Department for Ethics in the Ministry of Administration, but there were only 77 complaints with regard to ethical standards of state servants in 2008 and 2009 filed through this Department. In addition, there were 296 commissioners for ethics appointed in state bodies in 2010 (data on the situation at the beginning of June 2010). As many as 355 ethical complaints were submitted in 2008. Only two civil servants have been fired on those grounds, and in 18 additional cases serious penalties have been imposed. In sum, disciplinary penalties have been imposed in only 20 cases, counting for only 5.6 per cent of the reported ethical cases. Only 0.03 per cent of the civil servants have been sentenced for ethical offences. As many as 416 complaints were submitted to these commissioners in various administrative bodies in 2009 (an increase of 17 per cent in comparison to 2008). It was decided in 356 cases that complaints were not firmly grounded, in 19 cases disciplinary responsibility was initiated, and in 41 cases the procedures have not been completed yet. The number of submitted complaints was 275 in 2010, 272 in 2011, 325 in 2012, 492 in 2013, 477 in 2014, 425 in 2015, and 367 in 2016.

In 2006 the Civil Service Commission was established as a semi-autonomous body competent for second-instance decisions in civil service cases. Because of its weak capacities, its results are moderate and autonomy limited.

A central state institution for in-service training started to function in June 2005. It operated as the Civil Servants' Training Centre within the Central State Office for Public Administration (until 2009) and the Ministry of Public Administration (after 2009) until 2011, when it was merged with the Academy of Local Democracy into a new institution called the State School for Public Administration. During eight years, these institutions performed 1,075 training programmes with 46,758 civil servants participating in them (Bošnjaković, 2015). Along with that, many training programmes have been organized by the other institutions, such as the Diplomatic Academy, the Judicial Academy, the Tax Administration, the Customs, the Ministry of Regional Development, etc.

\section{Service Delivery and Digitalization}

The main results with regard to service delivery have been achieved in the area of e-government and e-services. Organisational support to e-government started in 2000 when the Government's Office for Internetisation was established. Its results were mainly concentrated around the procurement of ICT equipment for state bodies. The next Government established the Central State Office for e-Croatia which was a proactive administrative organisation. Its modest success 
was supported by the then Government one of whose main goals was to support economic development. That is why one-stop shops for private businesses were designed within the HITRO.HR network as early as in 2004. The Office initiated several other smaller projects, supported the rest of state administration with regard to ICT implementation, prepared the first Strategy of e-Government Development 2009-2012 (adopted by the Government in January 2009), etc. However, due to the assessments that stronger coordination with the main body competent for public administration was needed, the Office was merged with the Ministry of Public Administration in 2011. One of the main results of further efforts in this area was the creation of an electronic system for providing administrative services called e-Citizen in 2014. A subsequent step was instigated in 2015 under the title e-Business, but only as a pilot project. The new, e-Croatia 2020 Strategy was adopted by the Government in May 2017.

There is a long tradition of general administrative procedural law on the territory of the former Yugoslavia. The first Law on General Administrative Procedures (LGAP) in Yugoslavia was adopted in 1930, only five years later than the well-known Austrian law of the same name, which served, at that time, as a model law for other countries. At the beginning of 1990, Croatia took over the Yugoslav LGAP of 1956, amended in 1965, 1977, 1978 and 1986 respectively, with minor adaptations. The Yugoslav GAPA was known as the longest administrative procedural law. It offered fairly good protection of citizens' rights. However, it was casuistic, court-imitating, and too complex, with many possibilities for ministries, state prosecutor's office, and other central state bodies to intervene in the final administrative act. Better legal protection of citizens' rights, simplification of administrative procedure, regulation of modern information and communication technology usage in the procedure, application of the main EU law principles and better efficiency of procedures, were among the main goals of administrative procedural reform that resulted in the adoption of the new Croatian LGAP and its entering into force from $1^{\text {st }}$ January 2010. The new Law has widened and strengthened the legal protection of citizens in their relations with public administration in line with the EU law principles, but it has been significantly less successful in reducing red tape, formalism and bureaucratization in public administration.

\section{Organization and Management of Government}

Decentralisation started in 2001 with the results which cannot be evaluated as the real success (see above, Chapter 1). Another decentralisation attempt was made in 2006. Although significantly less ambitious, limited to only two competencies (building permits and public roads), it was more successful.

In parallel with the decentralisation, the network of first-instance offices of state administration was reorganized in 2001. The first-instance county administrative departments, 175 of them, were merged and reorganized into only one state administrative office per county (20 of them in the whole country). The number of their staff was reduced significantly, from about 8,500 to about 2,600 in 2017 . In the same reform of 2001, offices were completely separated from the counties as autonomous second-tier governments. 
The Government elected at the end of 2003 proclaimed, among others, a "leanstate" policy, including the reduction of the number of ministries (from 21 to 13) and delegation of policy implementation to semi-autonomous public agencies. That is mainly why parts of the former Ministry of Justice, Public Administration and Local Self-Government were separated and transferred to the newly-established Central State Office for Public Administration. The process of agencification was at its peak in 2009 when 87 public agencies were identified. After the beginning of the economic and fiscal crisis, de-agencification started. The establishment of the Ministry of Public Administration in 2009 was based on the assessment that deagencification and other "rationalization" of public administration needed firmer political leadership and support and that the former Central State Office was not particularly adequate in that regard.

In the 2010-2012 period, 19 agencies and similar bodies were abolished, but seven new ones were established (Musa, 2014). As many as 75 public agencies remained. Another de-agencification attempt was based on the then Government's decision of 2015 which called for the abolishment of nine public agencies at the national level. However, that decision has been never implemented due to weak political support and strong bureaucratic resistances, meaning that the second de-agencification attempt failed. Preparation of the draft Law on Public Agencies launched at the beginning of 2017 was stopped simultaneously with political changes in the ruling coalition in April 2017.

The Functional Review project of 2008 recommended widening the competences, strengthening the capacity, and reorganizing the first-instance offices of state administration in order to transform them and their branch offices (91 of them) into one-stop shops able to provide integrated administrative services to citizens in about 110 towns. There was an attempt in that regard in 2014. An additional base for the application of the one-stop shop principle was found in the almost complete fragmentation of deconcentrated state administration. Namely, during the preparation of the new Strategy of Public Administration Development 2015-2020, which started at the end of 2013, it was found that 1,279 deconcentrated branch offices of state administrative bodies existed throughout Croatia, with approximately 65 per cent of all state administrative staff. Additionally, there are many branch offices of various public agencies and other public institutions (Koprić, 2015). Fragmentation and lack of coordination and coherence were also found in state inspections. This worrying level of fragmentation called for the application of an integrative approach at the level of first instance state administrative bodies. However, that attempt was politically blocked at the beginning of 2015, partly because of poor preparation, and ended up as a complete failure. As was said (see above), the organisation of public administration is still one of its weakest sides.

\section{Policy Making, Coordination and Implementation}

Three central state bodies were established in the beginning of 2000 with highly important political tasks. The first one was the Ministry of European Integration which was given the task of preparing, as quickly as possible, all necessary measures for the beginning of formal EU integration. The second one was 
the Ministry of Justice, Public Administration and Local Self-Government. It was obliged to prepare a complete reform of the political system and deep constitutional reform, as well as to instigate far-reaching decentralization of the country and necessary administrative reform. The third one was the Office for Development Strategy whose main task was to prepare the "Croatia in the $21^{\text {st }}$ Century" Strategy. All three bodies prepared and performed very important horizontal policies and tasks (EU integration, decentralization and administrative reform, and strategic planning) proactively and with very good initial results.

After the political change, the new Government continued to firmly support EU integration policy. After gaining EU candidate status, it established a complex, but well-organized network of bodies and other institutional forms for EU accession negotiations. Despite minor criticism, this may be easily assessed as an example of a successful coordination mechanism.

In parallel, the same Government wanted to improve the business climate, simplify administrative functioning, reduce red tape, and improve legislative procedure. For that, it established a special unit for simplification and deregulation, responsible only for the Hitrorez project which lasted ten months. Several thousand regulations were considered, 706 of them were recommended to be abolished and 865 to be simplified. The Government formally accepted 1,571 recommendations and established the Office for Regulatory Impact Assessment in 2007. After two years, only 366 recommendations were implemented (23.3 per cent) and the Office was abolished (Musa, 2011). The Law on RIA adopted in 2011 designated this task to the Government Legislation Office.

In addition to RIA, which has to encompass the assessment of impacts on the economy, socially sensitive and other groups with special interests and needs, and on the environment and sustainable development, in 2011, the Government imposed the obligation of assessing fiscal impacts of new laws and regulations. In 2012, the Government adopted the Strategy of RIA and the Decree on RIA. However, better regulation policy was not a particular success. For example, although the Legislative Plan for 2013 requested that 61 laws out of 344 (17.7 per cent) that underwent the legislative procedure be accompanied by RIA, RIA was prepared for only 22 of them (6.4 per cent of the total number of laws in parliamentary procedure in 2013; i.e. 33.4 per cent of the laws planned for RIA procedure).

Another way of strengthening coordination in public administration was through the establishment and functioning of HITRONet, the electronic communication network for exchange among administrative and state bodies, agencies and institutions on the common governmental communication ICT platform. The development of that network was initiated by the Government's decision of 2002. It became fully functional later, providing a common ICT platform for all state bodies, including state administrative bodies and courts, large public agencies and other public institutions. Today HITRONet encompasses 46 central state locations and more than 400 various public institutions dispersed throughout Croatia. As of June 2009, HITRONet has been connected with sTESTA (secured Trans European Services for Telematics between Administrations). 
There were two strategic documents that set up the framework for administrative modernization policy, which includes improved policy making, better coordination and more efficient implementation of government policies. The first one was the State Administration Reform Strategy 2008-2011, adopted by the Government in 2008, while the second was adopted by the Parliament in 2015, widening its scope to local self-government system and public agencies.

Weaknesses of the first Strategy (2008) included: a) broad and insufficiently precise indicators of implementation progress, which made the monitoring and evaluation of its implementation difficult; b) a body in charge of evaluating its results (the National Council for Evaluation of State Administration Modernisation), established in autumn 2008, was soon dissolved (in summer 2009) without any significant output; c) many reform measures were defined only on the normative basis, d) there was neither a financial plan nor funds for Strategy implementation. There was an attempt to amend the Strategy in 2010, but it ended without results. An official assessment of the Ministry of Public Administration, included in the text of the new 2015-2020 Strategy, stressed that about 89 per cent of all reform measures were implemented, partly implemented, or in the course of implementation at the moment of the new Strategy adoption (Strategija, 2015, p. 4).

The new Strategy (2015) contains 17 goals with regard to better provision of administrative services, development of human potentials, and improved system of public administration. As many as 42 serious reform measures have been programmed for their implementation. Six additional measures have been programmed and a special institutional arrangement invented for the Strategy implementation. The end of the mandate prevented the Government from starting a real implementation process and even an institutional arrangement for implementation was not established. Few measures were implemented during the extremely short Government mandate in the first part of 2016. The first Action plan for the implementation of the Strategy adopted by the Government in September 2015 was not approved by the European Commission (EC), the second, prepared in 2016, was not adopted because of the early elections, and the third one, later approved by the EC, was adopted by the Government in December 2016.

\section{Overall Implementation Dynamic and Reform Outcomes}

\section{Implementation Dynamics}

The Croatian public administration reforms have been conducted in a patchy and bumpy manner. An attempt to initiate a more systematic reform, by the Strategy of State Administration Reform of 2008, has resulted in modest success, as only some of the measures have been fully or partially implemented. Administrative reform is incremental even in the most positive examples, while it stagnates in a wide number of areas.

The basic principles of European good governance frame the majority of reform steps and measures, as they are widely accepted, at least at the formal level. However, realisation of such principles is weak, slow, eluding, hesitating and 
equivocal. Dominant politics has had a decisive role, while top professionals and academia have been neglected. Business community, citizens and civil society have some influence on the processes, but not substantive. The media have mainly supported administrative modernization, at least during last decade. Support from the general public is modest.

The dominant top-down approach to PAR in a majority of cases functions in a negative, preventive manner. It means that the dominant political actors select, from the menus offered by business community, academia, civil society and other actors, only those rare reform components, directions and measures which are not politically sensitive for them.

There are only a small number of cases in which dominant political actors have instigated well-programmed, comprehensive reforms, and continuously and persistently supported their realisation. Only three reform attempts have enjoyed firm political support: a) decentralisation at the beginning of the new Millennium, b) implementation of e-government and digitalisation policies (continuously), and c) harmonisation with the acquis communautaire and EU administrative standards, during the EU accession process. However, even in these cases the political support has not been unconditional. Only in rare examples have continuous efforts been invested into a reform direction. Such is the case of e-government development with slowly progressing solutions for the electronic delivery of some public services to citizens and businesses.

Additionally, the dominant political actors have searched for the windows of opportunity in cases when they are interested in promoting and implementing certain administrative changes, but there has not been favourable environment. For example, reorganisation of the first-instance state administrative bodies in the 2014-2015 period. Certain reform measures have been promoted halfheartedly, because nobody can refuse them easily (for example, anti-corruption measures). A period of political instability with early general elections in 2016 (less than a year after the regular general elections), change in the ruling coalition and change of political officials of the Ministry of Public Administration in 2017 added to the implementation complexity. Lack of political will has, from time to time, been substituted or warmed by the EU conditionality policy, European semester recommendations, or similar tools in the hands of external players.

However, not only political unwillingness hinders administrative modernisation, but also lack of administrative capacities for managing reforms, bureaucratic resistances, social rebuffs and even impedance from parts of academia (for example, in regard to administrative procedural simplification). In many cases, reform measures have been undertaken in reaction to dissatisfaction or pressure from the public or media. A well-known example of the abolishment of the Office for Regulatory Impact Assessment and its relocation to the Legislation Office (in 2009) shows that such measures may be senseless, superficial, costly and counter-productive.

A vast majority of decisions about administrative reforms are based on pure partisan political weighting without any evidence and professional preparations. Policy design is generally weak, monitoring formal and evaluation almost non- 
existent. Political decisions are simply and directly transposed to regulations. Warnings about weak policies, low quality of law preparation, accumulation of inconsistent laws, and non-existent and formalistic RIA have regularly come from domestic professional associations and external players. Thus, the Academy of Legal Sciences in its Statement of 11 June 2014 warned about many deficiencies, problems, and a "crisis of the Croatian legal system". Low quality of the rule of law and evidence-based instruments was stated in the 2015 Bertelsmann report (Petak et al., 2015). It has recently been found that decentralisation reform initiated at the beginning of the Millennium has never been officially evaluated (Koprić, Đulabić, 2016).

\section{Linkage to European Semester Documents}

Croatia has been assessed and monitored under the European Semester for five years, since it joined the Union on $1^{\text {st }}$ July 2013. During the 2014-2018 period there are similar recommendations addressing what the EU considers to be one of the most important public governance problems in Croatia (see Table A). In 2014 Croatia was recommended to “... address the high level of fragmentation and overlapping responsibilities ... across various levels of government and at central governmental level between ministries and agencies ..." (CSR6). In the following year, the recommendation was a bit stronger and required Croatia to " $[R]$ educe the extent of fragmentation and overlap between levels of central and local government ..." (CSR4).

In 2016, the recommendation was formulated similarly, but more realistically and with some refinement. It again asks Croatia to "[B]y the end of 2016, start reducing fragmentation and improving the functional distribution of competencies in public administration to improve efficiency and reduce territorial disparities in the delivery of public services." (CSR3). This recommendation took into account, for the first time, citizens and the business orientation of public administration, arguing that the purpose of required changes is not only improved administrative efficiency per se, but harmonized delivery of public services throughout country. Also, CSR3 contained the second part requiring harmonization of "... the wage-setting frameworks across the public administration and public services ..." which needed to be achieved "[I]n consultation with social partners".

Country specific recommendations given to Croatia have delineated three urgent governance reform tasks: a) changes in the structure of local governments, by creating less fragmented structure of local governments in order to reduce territorial disparities in the delivery of public services, b) "... rationalising the system of state agencies ..." to reduce overlap between ministries and agencies, and c) harmonization of salary schemes in public administration and public services.

Such recommendations are in line with what domestic scientific and the professional community has been assessing as the main problems for quite some time. Territorial rationalisation as a precondition for more effective service delivery on the whole state territory was the first and basic recommendation offered in the document "Thirty recommendations for reforming system of public 
governance in Croatia" prepared by the Institute of Public Administration and presented on $7^{\text {th }}$ May 2014 in the Croatian Parliament. Aside from local self-government system and decentralisation, these recommendations were given with regard to strengthening absorption capacity for EU funds, betterment of ethics and public integrity, plus improvements in policy making and strategic planning, public transparency, and civil service (Preporuke, 2014). It is interesting that these lists of the most urgent administrative problems and recommendations for improvement largely overlap with some external actors' assessments and suggestions (comp. the World Bank's Croatia policy notes 2016: restoring macroeconomic stability, competitiveness and inclusion).

Advocating for structural reforms in the local self-government system and in the system of public agencies was started in 2010 by the Croatian Academy of Science and Arts and the Institute of Public Administration. Both institutions have organized several conferences and prepared publications in that regard. Finally, the Strategy of Public Administration Development 2015-2020 adopted by the Croatian Parliament clearly addresses these issues.

Additional comments contained in staff working documents have offered a more detailed and precise picture of the Croatian governance system reform needs (Koprić, 2017a). According to staff working documents, they are concentrated around the following issues in all five reform dimensions analysed in this report:

- Anti-corruption policy,

- Design of a merit-based civil service system,

- Reduction of administrative burden on companies,

- More effective, easily accessible and digitized service delivery harmonized throughout state territory,

- Strengthening capacity for full, effective and timely use of EU funds, with an appropriate monitoring and evaluation system,

- Reduction of administrative fragmentation in the local self-government system and at the national level (ministry - state agencies),

- Evidence-based policy making, betterment of administrative system coordination, improvements and acceleration of public administration reform, including decentralisation and management of public finances, and, generally, better management of the public governance system.

It is interesting that the civil service and human resource management have not attracted as much attention in European Semester documents as anticorruption, service delivery, policy making, organisation, management and coordination of the public governance system. On one hand, this is not a real surprise bearing in mind the solid tradition in Croatia of developing civil service regulation even during socialism, when even a sort of general performance management system for public administration was developed (Hrgovan, 1989). On the other hand, strong reliance on regulations and a formalistic approach, widespread in Croatia, have caused negligence of substantive issues such as evidence-based policy making, quality service delivery, strong public integrity, or work on the whole-of-government or joined up governance concepts. It should be added that human resource management and especially 
issues of proper education and training of civil servants, professionalization, depoliticisation and integrity of civil servants still cannot be treated as solved problems.

The overall assessment of progress in implementation of country specific recommendations is bitter, stressing humble reform ambitions and efforts as well as persistent problems. A general conclusion is that "[T]he reform of public administration has not been taken forward in substance."

Documents and recommendations provided in the frame of the European Semester may be assessed as highly relevant, because they are based on rather solid information and understanding of specificities of the public governance system, its functioning and development, and efforts in administrative modernization in Croatia. It seems that the European Commission gathered a lot of information during the Croatian accession process. Croatia was a carefullymonitored country during the accession decade. The OECD-Sigma alone submitted and published more than 40 reports on the progress in various administrative fields.

\section{Reform Outcomes}

Despite many reform initiatives and efforts, Croatia is still positioned among those countries with moderate competitiveness and inefficient public administration. According to the World Economic Forum's Global Competitiveness Report 2016-17, Croatia is ranked $74^{\text {th }}$, with a score of 4.15 points out of 7 , slightly improving its status in comparison with the previous year $\left(77^{\text {th }}\right.$ place, score 4.07$)$. Fragmented and inefficient public administration characterised by low cost-effectiveness and large public expenditures significantly contributes to such assessments. Many assessments indicate a slow pace of administrative modernisation and many other problems. However, certain results have been achieved.

Substantial progress is observable in transparency, openness and accountability policies, especially after the beginning of formal EU accession process. The results have been much better since the first ever Public Information Commissioner was appointed by the Parliament in 2013. The Commissioner has put considerable efforts in the establishment of an effective system of public transparency. However, there are some resistances from public bodies and institutions with regard to the new transparency and accountability mechanisms. An anti-corruption system has been designed, but eradication of corruption is not an easy task. Deep politicisation of the public sector and certain characteristics of societal culture are among the factors that hinder better results in combating corruption, especially high level public sector corruption.

Fragmentation of the civil service law which differentiates between two types of public staff (servants and employees) in no less than five categories, with the fifth one in public companies, is one of the unresolved tasks. Problems with motivation, performance management and salary system are among those that need additional attention. Some results have been achieved in regard to civil service ethics, despite serious lack of political support to that issue. The Civil Service Commission suffers from similar lack of political sup- 
port, while the support to the State School of Public Administration is a bit better, as are its results.

E-government policy has been among the rare reform streams which continuously, and without major political disturbances, attracts significant political support and budget resources. Many elements of strategic, legal and institutional frameworks for effective electronic delivery of public services have already been established, but there is a lot of space for further improvements in providing electronic public services to citizens and businesses. Usage of electronic services is modest. For example, currently less than 8 per cent of citizens use the e-Citizens service. The digital divide is still a problem. Additional problems include an uneven level of electronic services for different groups and unequal access to them from various parts of the state territory due to differences in ICT infrastructure. Beside the existence of many special administrative procedures that deviate from the general administrative procedural rules, regulation of general administrative procedure has not been focused on reducing red tape, formalism, and bureaucratisation of public administration.

Incomplete implementation of the 2001 decentralisation, which did not tackle the territorial consolidation foreseen in the decentralisation programme, resulted in regional and local disparities in the provision of local services and caused a need for state budget financial support. Continuous financial support without sound monitoring and evaluation resulted in unjustified differences in state budget expenditures for the same services in different counties. It seems that counties apply the political criteria for distribution of such financial resources to different towns and municipalities on their respective territories. Due to lack of performance management mechanisms, separation of agencies from their competent ministries has not resulted in improved efficiency and better results, but in further administrative fragmentation without accountability. Examples of good practice in the system of state agencies do exist, especially when speaking about independent regulators, but generally, implementation of the agencification concept cannot be evaluated as successful. The first de-agencification attempt (2009-2010) ended up as a moderate success, while the second one (2014-2015) was a failure. The third generator of administrative fragmentation is a complex and irrational structure of deconcentrated administration, i.e. a structure that consists of first instance offices of state administration and branch offices of ministries, public agencies, public institutions and other state administrative bodies. An attempt to start their transformation to one-stop shops throughout the country can be assessed as a failure.

Several governments designed and followed clear reform concepts during the 2010s, starting with the one elected in the beginning of 2000. Although their reform concepts partly politically diverge, they invested significant efforts in implementing them. However, none designed or established a sustainable institutional solution for the management of public governance reforms. Discontinuation in that regard has accentuated low policy making and coordination capacities. It has also diminished the capacity of programming and 
managing sound and comprehensive administrative reforms. The first strategic document of 2008 was of limited significance, while the second one, adopted in 2015, has produced only minor results, due to the complex and unique political circumstances from autumn of 2015 to late 2017.

\section{Conclusion and reform proposals}

Croatia has shown rather expected consequences through its mixed administrative traditions. The tradition inherited from the pre-socialist period is mainly based on the continental European "Weberian" model of state bureaucracy impregnated with legalism, formalism, rigid leadership and discipline. The tradition from socialism partly deviates from that of other former socialist countries because of a well-known self-management experiment, which raised the sense of citizens' participation in local matters and issues of minor importance. However, similar to the other socialist countries, there was a parallel system of coordination in the most important aspects of public governance, through the dominant political party based on arbitrary political will in a quasi-dictatorial manner.

That is probably why over-politicization co-exists with legalism, formalism and red tape. One of the results is low reform, innovation and initiative capacities. Professionalism and development of proper high quality administrative education and training have never been highly appreciated. Derivations of such a situation can be found in weak strategic planning and policy making, almost non-existent professional management of administrative organizations and processes, costly and ineffective public service delivery, politically sponsored recruitments in the civil service at all governmental levels, resistances to rational organization of public administration, etc.

Despite wide acceptance of decentralisation as a political goal, at least on the surface, dominant political parties and actors are in favour of retaining the current division of public tasks among the central bodies and local governments. Not a single local government ever questioned the constitutionality of this model of public tasks division, although it is not in line with the constitutional provisions at first glance. This is paradoxical only if blame games and inherited political styles are not taken into account.

Overall public governance style is still highly centralistic in spite of formal adoption of the European Charter of Local Self-Government and some other documents and standards. The main channels of central influence are through overdeveloped networks of deconcentrated state administrative offices and through state budget transfers. Naturally, intra-party political coordination plays a certain role. However, in most recent stage, some signs of multi-level governance and cooperation between governments and bodies at different levels, in line with the best European experiences, can be observed.

E-government policy is one of the rare examples of unquestionable political support. Transparency policy is close to that position, but only in the most recent period, and mostly because of external (EU) pressures. External pressure is an important reform factor, although domestic political concepts, if they exist, 
may engage stronger support. Examples are decentralisation in the beginning of the 2000s and reforms aimed at improving the business climate during the 2000s. Austerity policy at the end of the 2000s and in the beginning of the 2010s resulted in the first de-agencification reform (2009-2010), the introduction of strategic planning, and some other changes in the public sector (cf. Koprić et al., 2018). The beginning of public and professional debate about harmful effects of administrative fragmentation at the central and local levels is also connected with economic, financial and fiscal crises of that time, but still without significant results.

The following reform measures are advisable under current circumstances:

- Preparation of comprehensive local government reform with consolidation at both local levels (basic and county level) and possible decentralisation to a much smaller number of regional governments,

- Reorganisation of deconcentrated administration with design of one-stop shops for more effective delivery of public services throughout state territory,

- Accelerated development of electronic public services delivery to citizens and companies,

- Legal changes aimed at substantive administrative simplification,

- Robust implementation of anti-corruption policy at all governance levels,

- Significant improvements in human resources management and development of high-quality administrative education,

- Creation of a strong institutional solution for programming, managing and evaluating administrative reforms, or much stronger support to the Ministry of Public Administration,

- $\quad$ Review and revision of strategic planning, policy-making and legislative processes at all governmental levels.

\section{REFERENCES}

1. Bošnjaković, D. (2015). Stručno usavršavanje hrvatskih državnih službenika u Centru za stručno osposobljavanje i usavršavanje službenika i Državnoj školi za javnu upravu. Završni specijalistički rad. Zagreb: Sveučilište u Zagrebu.

2. Hrgovan, Lj. (1989). Pristup racionalizaciji općinskih organa uprave s okvirnim mjerilima potrebnog fonda rada i katalogom poslova i zadataka. Zagreb: Narodne novine. 
3. Izvješće (2016). Izvješće o provedbi Zakona o pravu na pristup informacijama za 2015. godinu. Available at: http://www.pristupinfo.hr/izvjesce-o-provedbi-zakona-o-pravu-na-pristupinformacijama-za-2015-godinu-povjerenika-za-informiranje/ (accessed: 16 January, 2019).

4. Izvješće (2017). Izvješće o provedbi Zakona o pravu na pristup informacijama za 2016. godinu. Available at: http://www.pristupinfo.hr/dokumenti-i-publikacije/ (accessed: 16 January, 2019).

5. Koprić, I. (2015). Teritorijalna organizacija Hrvatske: prema novom uređenju. In: Nova upravno-teritorijalna organizacija Hrvatske. Zagreb: HAZU, pp. 21-44.

6. Koprić, I. (2017). Public Administration Characteristics in Croatia. EUPACK Project, Task 1 Report.

7. Koprić, I. (2017a). Public Administration Reform Trends and Reform Dynamics in Croatia. EUPACK Project, Task 2 Report.

8. Koprić, I. \& Đulabić, V. (2016). Evaluation of Decentralisation Programme in Croatia: Expectations, Problems, and Results. In: I. Koprić, H. Wollmann, G. Marcou (eds.) Evaluating Reforms of Local Public and Social Services in Europe: More Evidence for Better Results. London: Palgrave Macmillan.

9. Koprić, I., Škarica, M. \& Manojlović, R. (2018). Local Public Services and Austerity Measures in Croatia: Adaptations of the Resilient Social Model through the Central-Local Power and Blame Games. In: A. Lippi, T. Tsekos (eds.). Local Public Services in Times of Austerity across the Mediterranean Europe. London: Palgrave Macmillan.

10. Manojlović, R. (2016). Preduvjeti za funkcioniranje sustava upravljanja radnim izvršenjem službenika. In: I. Koprić, J. Džinić, R. Manojlović (eds.) Upravljanje kvalitetom i učinkovitošću u javnoj upravi. Zagreb: Institut za javnu upravu.

11. Medvedović, D. (2013). Novine u pravnom uređenju koncesija. In: Zbornik radova 51. Susreta pravnika. Opatija: Hrvatski savez udruga pravnika u gospodarstvu, pp. 79-116.

12. Musa, A. (2011). Croatian Public Administration on the Road to the European Union: What to Expect while Expecting? Etudes Européennes, $14^{\text {th }}$ December 2011. Available at: http:// www.etudes-europeennes.eu/images/stories/A_look_at_Croatia/ENA-Anamarija_ Musa-7_Sept_2011301111js_FINAL.pdf (accessed: 16 January, 2019).

13. Musa, A. (2014). Agencijski model javne uprave. Zagreb: Pravni fakultet.

14. Petak, Z., Bartlett, W. \& Bönker, F. (coordinator) (2015). Sustainable Governance Indicators: 2015 Croatia Report. Gütersloh: Bertelsmann Stiftung.

15. Preporuke (2014). Trideset preporuka za reformu sustava javnog upravljanja Foruma za javnu upravu. Zagreb: Institut za javnu upravu. Available at: http://www.iju.hr/page15/files/ Preporuke.pdf (accessed: 16 January, 2019).

16. Ratković, K. (2008). Analiza poslova u hrvatskoj državnoj upravi. Hrvatska javna uprava, vol. 8, no 4 , pp. 867-882.

17. Strategija (2015). Strategija razvoja javne uprave za razdoblje od 2015. do 2020. godine. Narodne novine, no 70/15.

18. WB (2016). Croatia Policy Notes 2016: Restoring Macroeconomic Stability, Competitiveness and Inclusion. Washington: The World Bank.

19. WGI (2015). Worldwide Governance Indicators. Available at: http://info.worldbank.org/ governance/wgi/index.aspx\#reports (accessed: 16 January, 2019). 


\section{Table A: List of Country Specific Recommendations (year by year, recommendations relevant to the scope of this report in bold)}

\begin{tabular}{|c|c|}
\hline 2011 & - \\
\hline 2012 & - \\
\hline 2013 & - \\
\hline 2014 & $\begin{array}{l}\text { CSR6 "(...) Address the high level of fragmentation and overlapping } \\
\text { responsibilities by streamlining administrative processes and by clarifying } \\
\text { the decision-making and accountability framework across various levels } \\
\text { of government and at the central government level between ministries } \\
\text { and agencies (...)" }\end{array}$ \\
\hline 2015 & $\begin{array}{l}\text { CSR } 4 \text { "Reduce the extent of fragmentation and overlap between levels } \\
\text { of central and local government by putting forward a new model for functional } \\
\text { distribution of competencies and by rationalising the system of state agencies (...)" }\end{array}$ \\
\hline 2016 & $\begin{array}{l}\text { CSR3 "By the end of 2016, start reducing fragmentation and improving the } \\
\text { functional distribution of competencies in public administration to improve } \\
\text { efficiency and reduce territorial disparities in the delivery of public services. } \\
\text { In consultation with social partners, harmonise the wage-setting frameworks } \\
\text { across the public administration and public services (...)" }\end{array}$ \\
\hline \multirow[t]{2}{*}{2017} & $\begin{array}{l}\text { CSR } 4 \text { "Reduce the fragmentation and improve the functional distribution } \\
\text { of competencies in public administration, while enhancing the efficiency and } \\
\text { reducing territorial disparities in the delivery of public services. In consultation } \\
\text { with social partners, harmonise the wage-setting frameworks across the public } \\
\text { administration and public services." }\end{array}$ \\
\hline & $\begin{array}{l}\text { CSR5 "Speed up the divestment of State-owned enterprises and other State assets, } \\
\text { and improve corporate governance in the State-owned enterprise sector. } \\
\text { Significantly reduce the burden on businesses stemming from costs } \\
\text { of regulation and from administrative burdens }(\ldots) \text { " }\end{array}$ \\
\hline \multirow[t]{2}{*}{2018} & $\begin{array}{l}\text { CSR3 "Reduce the territorial fragmentation of the public administration, } \\
\text { streamline the functional distribution of competencies and enhance the } \\
\text { capacity to design and implement public policies. In consultation with social } \\
\text { partners, introduce harmonised wage-setting frameworks across the public } \\
\text { administration and public services." }\end{array}$ \\
\hline & $\begin{array}{l}\text { CSR4 "Significantly reduce the burden on businesses arising from parafiscal } \\
\text { charges and from cumbersome administrative and legislative requirements." }\end{array}$ \\
\hline
\end{tabular}

